Review

\title{
Gene Therapy Approaches to Functional Cure and Protection of Hematopoietic Potential in HIV Infection
}

\author{
Tetsuo Tsukamoto \\ Department of Immunology, Kindai University Faculty of Medicine, Osaka 5898511, Japan; \\ ttsukamoto@med.kindai.ac.jp; Tel.: +81-723-66-0221
}

Received: 7 February 2019; Accepted: 6 March 2019; Published: 11 March 2019

\begin{abstract}
Although current antiretroviral drug therapy can suppress the replication of human immunodeficiency virus (HIV), a lifelong prescription is necessary to avoid viral rebound. The problem of persistent and ineradicable viral reservoirs in HIV-infected people continues to be a global threat. In addition, some HIV-infected patients do not experience sufficient T-cell immune restoration despite being aviremic during treatment. This is likely due to altered hematopoietic potential. To achieve the global eradication of HIV disease, a cure is needed. To this end, tremendous efforts have been made in the field of anti-HIV gene therapy. This review will discuss the concepts of HIV cure and relative viral attenuation and provide an overview of various gene therapy approaches aimed at a complete or functional HIV cure and protection of hematopoietic functions.
\end{abstract}

Keywords: human immunodeficiency virus; acquired immunodeficiency syndrome; hematopoietic stem/progenitor cells; gene therapy

\section{Introduction}

Human immunodeficiency virus (HIV) infects $\mathrm{CD}^{+} \mathrm{T}$ cells and causes acquired immunodeficiency syndrome (AIDS). AIDS remains as a global threat due to multifactorial reasons, including the difficulty in developing an effective vaccine [1]. According to The Joint United Nations Programme on HIV/AIDS (UNAIDS), in 2017, about 36.9 million people were living with AIDS while only 21.7 million patients were receiving antiretroviral therapy (ART), resulting in about 1.8 million newly HIV-infected people per year [2]. Although ART can limit the size and distribution of HIV reservoirs depending on the earliness of its initiation, it cannot eliminate latent HIV infections from the host and thus, a lifelong prescription is required for suppressing viral rebound from the reservoirs [3]. Therefore, further exploration is vital to discover new treatment options and effective vaccines [4].

The depletion of memory $\mathrm{CD} 4^{+} \mathrm{T}$ cells preceding AIDS manifestation may be mainly due to the infection of these cells. However, HIV may also reduce the production of naïve T cells by infecting $\mathrm{CD}^{+}$thymocytes [5-8]. On the other hand, although the dynamics of hematopoietic stem/progenitor cells (HSPCs) in HIV-infected settings is still unclear, it is well established that HIV infections are associated with hematological changes, such as anemia and pancytopenia [9]. These hematological changes are likely due to the modified HSPCs and hematopoietic potential of the host. Therefore, a cure for HIV disease should consider not only the absence of newly HIV-infected CD4 ${ }^{+}$cells but also the normal production rates of $\mathrm{CD} 4^{+} \mathrm{T}$ cells and other hematopoietic cells. To achieve an HIV cure in its strict sense, the protection of bone marrow hematopoietic functions is essential (Figure 1). 


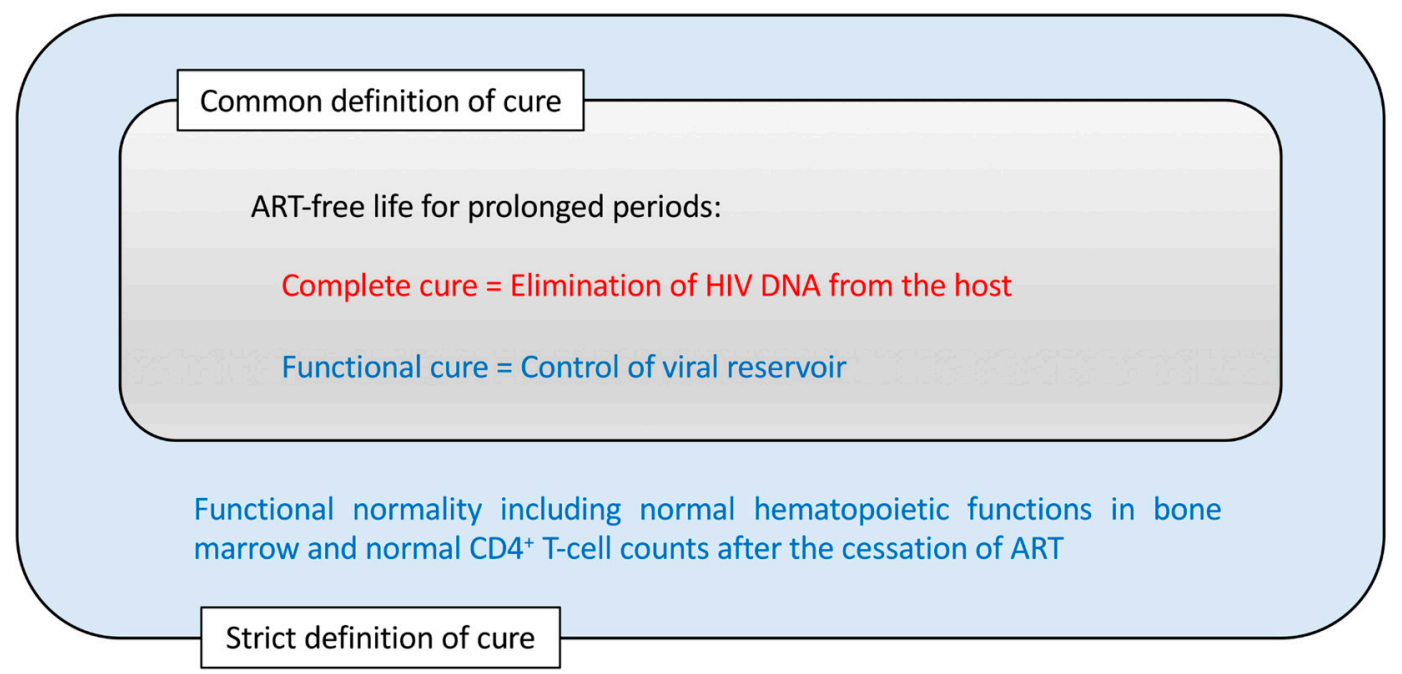

Figure 1. The concepts of human immunodeficiency virus (HIV) cure. A cure for the HIV disease is commonly interpreted as antiretroviral drug therapy (ART)-free life without viral rebound for prolonged periods. In addition, the cure for bone marrow dysfunctionalities observed in HIV-infected patients could be included in a stricter definition of a HIV cure.

This review first describes the current evidence of modified bone marrow hematopoietic potential in HIV infection, leading to the strict definition of an HIV cure. It then explains how anti-HIV gene therapy methods applied to HSPCs can support the preservation of hematopoietic potential and a functional cure. This will be followed by an overview of different potential gene therapy methods for achieving this goal.

\section{Evidence of Modified CD $34^{+}$Cell Dynamics and Functions in HIV Infection}

HIV-1 may cause the loss of primitive hematopoietic progenitors without directly infecting these cells [10]. However, HIV infection does not cause the complete loss of CD34 ${ }^{+}$stem cells and therefore, it is possible to harvest stem cells from HIV-infected patients suffering from lymphoma [11] albeit with reduced efficiencies in relation to the reduction of peripheral $\mathrm{CD} 4^{+} \mathrm{T}$-cell counts [12] or reduced in vitro lymphopoiesis capacities [13]. The recovery of $\mathrm{CD} 4^{+} \mathrm{T}$-cell counts after successful antiretroviral drug therapy treatment may depend on the recovery of CD34 $4^{+}$cell counts [14].

A number of potential mechanisms have been suggested for the changes of CD34 ${ }^{+}$cells in the presence of HIV, such as reduced expression of the proto-oncogene $c-m p l$ on $\mathrm{CD}^{+} 4^{+}$cells [15] and elevated plasma stromal cell-derived factor 1 (SDF-1) levels [16]. HIV-1 infection causes the upregulation of inflammatory cytokine production that may affect the dynamics and functions [17] or induce Fas-mediated apoptosis [18] of bone marrow $\mathrm{CD} 34^{+}$cells. On the other hand, HSPCs themselves may contribute to inflammation and allergies [19]. This may be partly due to the fact that inflammatory signals are involved in HSPC development [20]. Recent evidence has suggested that CD34 ${ }^{+}$CD226(DNAM-1) bright $^{2}$ (DCR4 ${ }^{+}$cells may represent a subset of common lymphoid progenitors associated with chronic HIV infection and inflammation, reflecting the altered dynamics of natural killer cells and $\alpha / \beta$ T cells [21].

Humanized mouse models are useful for analyzing bone marrow $\mathrm{CD} 34^{+}$loss or changes after the HIV-1 challenge. In studies with humanized mice infected with CXCR4-tropic HIV-1 ${ }_{\mathrm{NL} 4-3}$, CD $34^{+}$ hematopoietic progenitor cells were depleted and showed impaired ex vivo myeloid/erythroid colony forming capacities after the challenge [22,23]. A reduction of bone marrow CD34 ${ }^{+}$cell counts after CCR5-tropic HIV-1 infection was also detected in another study [24]. Interestingly, the depletion of bone marrow CD34 ${ }^{+}$cells following CCR5-tropic HIV infection has been reported to depend on plasmacytoid dendritic cells [25] or to be associated with the expression of CXCR4 [26]. The latter implicates a potential role of the SDF-1/CXCR4 axis in the loss of $\mathrm{CD} 34^{+}$cells. Another recent in vitro 
study suggested that $\mathrm{CD} 34^{+} \mathrm{CD} 7^{+} \mathrm{CXCR} 4^{+}$lymphoid progenitor cells may be depleted in the presence of CXCR4-tropic HIV-1 in the coculture of HIV-infected cord-derived CD $34^{+}$cells with mouse stromal OP9-DL1 cells, which allow the differentiation of T cells [27].

\section{The Idea of Intracellular Immunization of HSPCs to Replace the Whole Hematopoietic System}

After this, it is important to consider how we could deal with hematopoietic changes in HIV infection. A potential solution is gene therapy. In 1988, David Baltimore presented his idea of intracellular immunization by gene therapy [28] and his concepts are still valid today. First, he suggested expressing inhibitory molecules against HIV in target cells. Second, he proposed using retroviral vectors to transduce cells although lentiviral vectors are widely used today. Third, he conceived the use of gene-modified HSPCs to replace the immune system of the hosts with an HIV-resistant one. These concepts may be summarized as intracellular artificial immune systems designed against HIV and working independently from HIV-specific $\mathrm{CD} 4^{+}$helper $\mathrm{T}$ cells, which are the most vulnerable HIV targets [29]. Since his work, a number of candidate gene therapies have been proposed and tested and are described later in this article.

\section{The Protection of Bone Marrow CD $34^{+}$Cells by an Anti-HIV Gene Therapy Demonstrated In Vivo}

However, there have been few reports so far that have tested the protection of CD34 ${ }^{+}$cells after HIV infection by gene therapy. This may be because viral suppression and $\mathrm{CD} 4^{+}$counts have been widely accepted as measures for the effect of gene therapies against HIV. However, the true goal for any gene therapy against HIV should be the protection of hematopoietic potential because this is another arm of the definition of AIDS, i.e., the loss of cellular immunity (Figure 1).

Regarding this, we have recently reported that a transcriptional gene silencing (TGS) approach using a short hairpin (sh) RNA, which is called shPromA (Figure 2), resulted in limited CXCR4-associated depletion of bone marrow CD34 ${ }^{+}$cells following CCR5-tropic HIV infection in humanized mice (Figure 3). This suggests that anti-HIV gene therapy can support the preservation of the hematopoietic potential of the hosts [26]. Further characteristics of shPromA and previous studies testing its efficacy as a functional cure gene therapy method is discussed in Section 8.

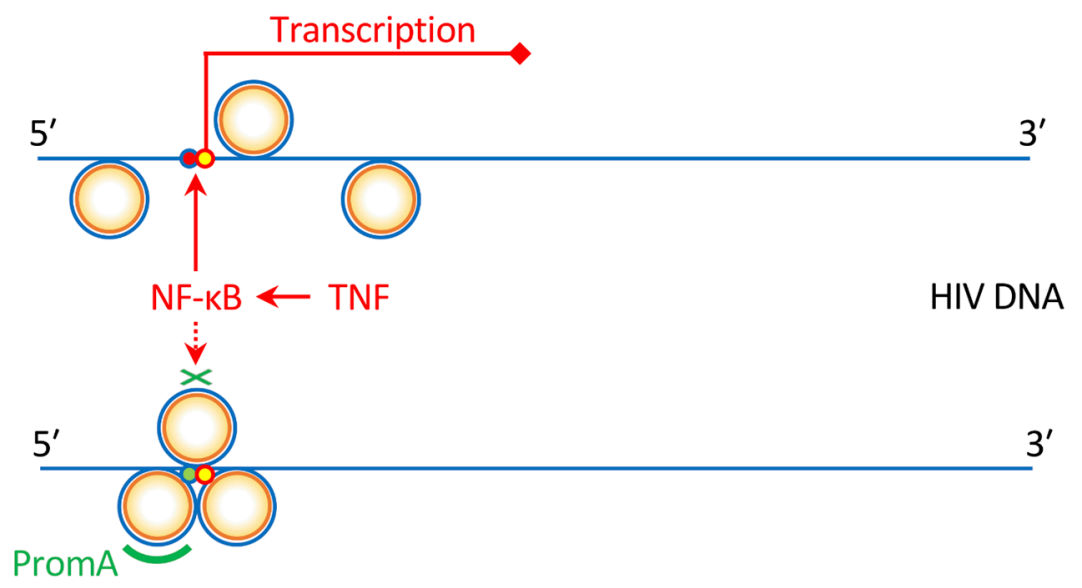

Figure 2. A schematic overview of PromA. PromA induces chromatin compaction in the human immunodeficiency virus (HIV)-1 promoter. This prevents HIV-1 DNA from reactivation, such as NF- $k$ B-mediated reactivation by tissue necrosis factor (TNF). For details on the molecular mechanisms involved in transcriptional gene silencing induced by PromA, see Klemm et al., 2016 [30] and Mendez et al., 2018 [31]. 
Unmanipulated $\mathrm{CD} 34^{+}$cells

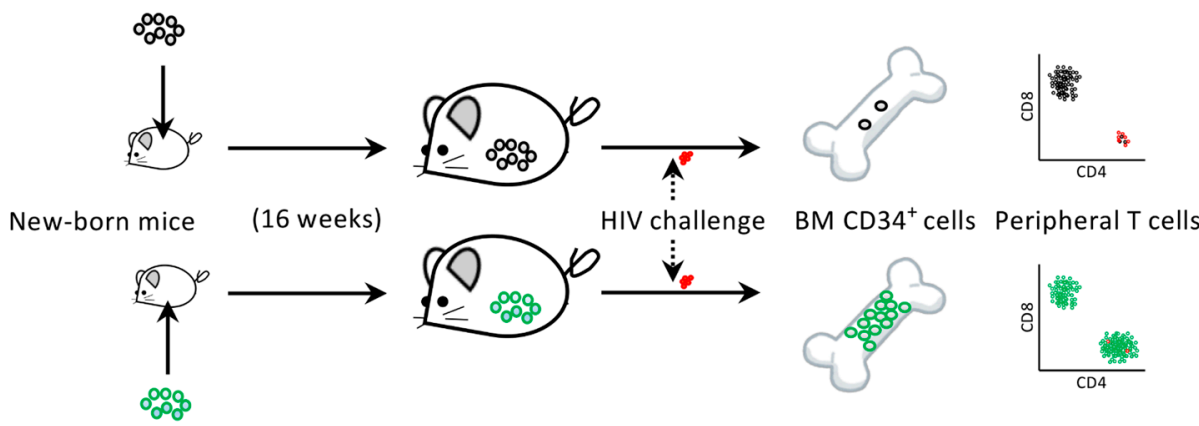

shPromA-transduced $\mathrm{CD} 34^{+}$cells

Figure 3. Summary of the humanized mouse study to test the efficacy of shRNA PromA (shPromA) [26]. Newborn NOD/SCID/Jak3 ${ }^{\text {null }}$ mice were intrahepatically transfused with unmanipulated cord-derived $\mathrm{CD} 34^{+}$cells or $\mathrm{CD}_{3} 4^{+}$cells lentivirally transduced with shPromA. Those mice showing engraftment of human cells were challenged with CCR5-tropic HIV-1 $1_{\text {JRFL }}$. Two weeks after the challenge, the mice were sacrificed and their bone marrow (BM) $\mathrm{CD} 34^{+}$cells and peripheral $\mathrm{T}$ cells were analyzed. Interestingly, mice transplanted with unmanipulated $\mathrm{CD} 34^{+}$cells showed unexpectedly low BM CD34 ${ }^{+}$cell counts 2 weeks after HIV infection, with concomitant depletion of peripheral CD4 ${ }^{+} \mathrm{T}$ cells. On the other hand, mice engrafted with shPromA-expressing $\mathrm{CD} 34^{+}$cells showed preserved BM CD $34^{+}$cell and peripheral $\mathrm{CD}^{+} \mathrm{T}$-cell populations at 2 weeks post challenge.

\section{Target Cells for Anti-HIV Gene Therapies}

Recent studies, including the above shPromA study, indicate that ideal anti-HIV gene therapy targets should be hematopoietic stem cells rather than more differentiated cells, such as peripheral CD4 ${ }^{+}$ $\mathrm{T}$ cells, because the transduced cells could engraft the host bone marrow and act as a lifelong source of HIV-resistant $\mathrm{CD} 4^{+}$cells $[26,32,33]$. Potential gene therapies using $\mathrm{CD} 34^{+}$cells have been investigated in vitro using cell culture experiments [26,34-36] or in vivo using humanized mice [26,35,37-40]. Furthermore, the transplantation of macaques with gene-modified autologous CD $34^{+}$cells followed by an infection with SIV has also been tested [41,42] although strategies may differ between gene therapies [33]. Based on such basic study results, the clinical trials using the transplantation of retrovirally or lentivirally gene-modified CD34 ${ }^{+}$cells in HIV-positive patients have been carried out [43-45]. Gene therapies of $\mathrm{CD} 4^{+}$cells have been considered as a cure for monogenic immune diseases. For example, the patients with adenosine deaminase deficiency [46], Wiskott-Aldrich syndrome (WAS) [47] and X-linked severe combined immunodeficiency [48,49] were successfully treated in clinical trials by transplantation of autologous $\mathrm{CD}_{3} 4^{+}$cells retrovirally or lentivirally transduced with the wild-type gene. Lentiviral vectors may be more efficient in gene transfer into resting stem cells at the G0/G1 phase compared with murine retroviral vectors [50]. If applied to the gene therapy of HSPCs, both retroviral and lentiviral vectors could have adverse effects, including the deregulation of gene expression [51] and the triggering of the p53 protein [52]. However, lentiviral vectors may be safer than retroviral vectors because the latter may occasionally cause insertional mutagenesis near the active start regions of genes, which could possibly lead to oncogenesis and cancers, such as leukemias [48]. Self-inactivating retroviral or lentiviral vectors lacking the U3 region of $3^{\prime}$ LTRs have further safety advantages [53]. Moreover, recent evidence has shown that the transplantation of WAS patients with autologous CD34 ${ }^{+}$cells transduced with lentiviral vectors encoding WAS protein results in the long-term survival of genetically engineered hematopoietic stem cells and lymphoid-committed progenitors [54]. Thus, this provides hope for lifelong protection from HIV.

Induced pluripotent stem cells (iPSCs) may also be candidates for anti-HIV gene transfer. iPSCs can be generated from the somatic cells of patients, which can differentiate to any cells in vitro and are expected to be utilized for the treatment of a broad range of genetic diseases [55-58]. Although CD34 ${ }^{+}$ cells can engraft in the bone marrow following transplantation and differentiate to hematopoietic cells 
in vivo, iPSCs may be more convenient for in vitro hematopoiesis compared to CD34 ${ }^{+}$cells because of their ease of culture [59]. Interestingly, the impact of shPromA-transduced iPSCs on the suppression of viral replication in vitro has recently been demonstrated, suggesting that the large-scale production of gene-modified monocytes or lymphocytes in vitro for adoptive therapy could be a future option [60]. Additionally, the generation of iPSCs from HIV epitope-specific $\mathrm{CD} 8^{+}$cytotoxic $\mathrm{T}$ cells followed by their redifferentiation into the identical epitope-specific $\mathrm{CD} 8^{+} \mathrm{T}$ cells for adoptive transfer could be an effective immunotherapy [61].

\section{Complete Cure vs. Functional Cure for HIV Infection}

Before describing individual anti-HIV gene therapy methods, this review looks back on Figure 1 to summarize two major strategies for the treatment of HIV infection. One is to eliminate all the HIV DNA copies within the host, which is termed a complete cure (Figure 1). In pursuing the feasibility of this goal, tremendous efforts have been made to (1) find a method to detect all the latently infected HIV DNAs in viral reservoirs and to (2) eliminate all the detected HIV DNAs so that the host would become sterile in terms of HIV infection [62]. Among the methods to achieve this, the so-called "shock and kill" method, in which the reactivation of the viral reservoir is attempted with a shock-inducing agent followed by the immune-mediated killing of the reactivated cells, has been widely investigated [63-67]. These efforts have been partly successful $[62,68]$. However, the difficulty of viral eradication in vivo is not limited to HIV but include other viruses that induce long-lasting latent infections, such as herpes simplex viruses, varicella-zoster virus, cytomegalovirus and Epstein-Barr virus, making them ineradicable [69]. HIV may differ from other latently infecting viruses as the viral replication from the latent reservoir can resume quickly even if the host is not considered to be immunocompromised [70]. Moreover, even in the case of the Berlin patient who exhibited no sign of HIV existence following allogeneic transplantation with CCR5- $\Delta 32 / \Delta 32$ hematopoietic stem cells, a complete cure was assumed rather than being fully demonstrated [71,72].

Alternatively, some potential gene therapy methods aim at a functional cure that is evidenced by the control of HIV replication below the limit of detection and the immune system being functionally normal despite residual cells harboring HIV proviral DNAs in the host (Figure 1) [68,73]. This approach might be more practical than the complete cure approach, given that many successful vaccines for chronic viral infections so far exert a functional cure rather than achieving the elimination of the targeted viruses [74]. In light of this, it could be stated that for those pathogens where an effective vaccine has not been developed to date, researchers could instead develop gene therapies aimed at a functional cure. In this way, there is an overlap between the concept of functional-cure gene therapy and the concept of vaccines against chronic pathogens [75]. In the next paragraph, the relevance of this is better clarified by looking at a similarity between live-attenuated vaccines and functional-cure gene therapy.

\section{Connection between Functional-Cure Gene Therapies and Live-Attenuated Vaccine Approaches}

Anti-HIV gene therapy might be compared to some of the vaccine candidates tested so far in order to better foresee its future direction. Live-attenuated vaccines have been tested in macaque AIDS models using simian immunodeficiency virus (SIV) strains [76-82]. After the infection of a host with a live-attenuated SIV or simian-human immunodeficiency virus (SHIV), the vaccine strain is controlled by T-cell response but remains slowly replicating in the infected host. This results in further immunization of the host to prepare for the subsequent superinfections of wild-type SIV or SHIV. Therefore, even if live-attenuated vaccines are powerful, they provide a functional but not a complete cure. This means that there is a scientific connection between live-attenuated vaccines and gene therapy approaches for a functional cure because the latter confer viral attenuation indirectly by rendering the host cells HIV-resistant (Figure 4a). The two distinct strategies can be collectively interpreted as the relative attenuation of the infected virus to the unmanipulated/gene-modified host cells (Figure 4b). Thus, relative viral attenuation might help the host immunity to control the virus [83]. 
(a)

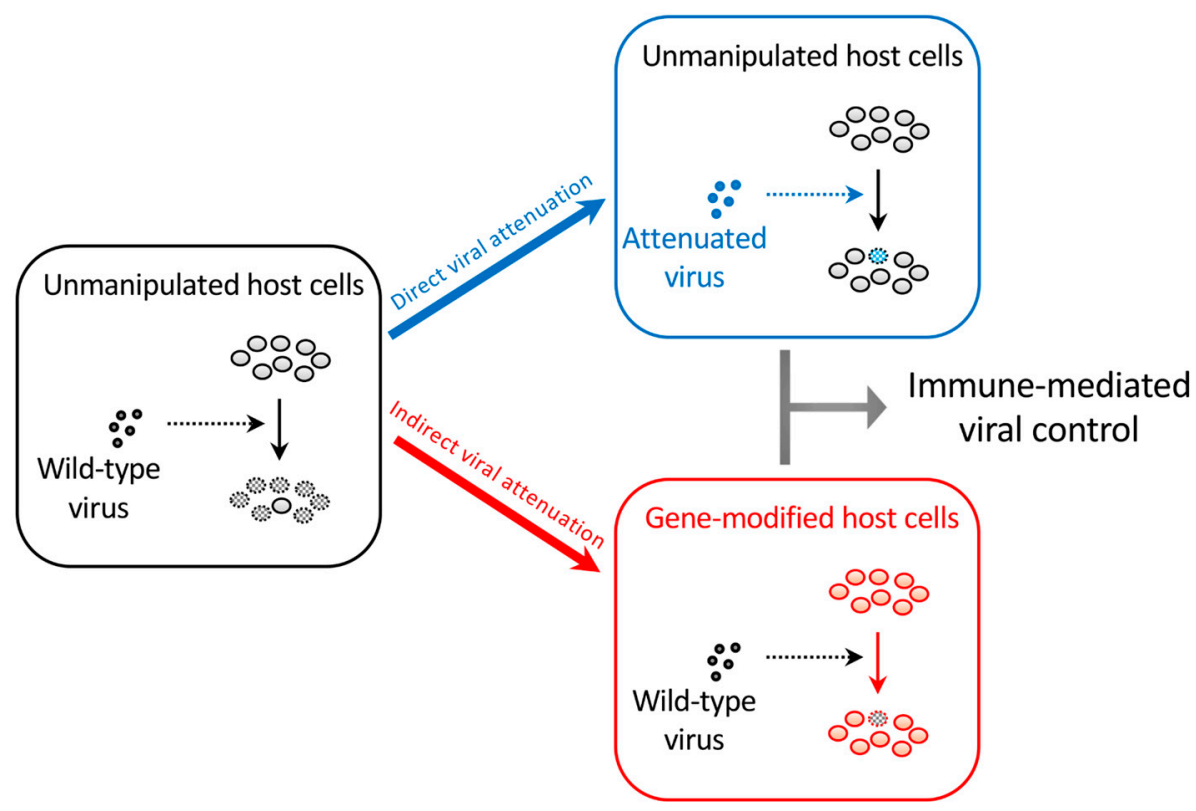

(b)

\section{Given the following parameters:}

$v_{0} \ldots$ Virulence of the wild type virus

$v_{1} \ldots$ Virulence of the live-attenuated virus

$r_{0} \ldots$ Viral resistance of the unmanipulated host cells

$r_{1} \ldots$ Viral resistance of the gene-modified host cells

"Relative viral attenuation $\boldsymbol{f}\left(\boldsymbol{t}_{1}\right)$ " can be defined as follows, using the direct viral attenuation index $\left(v_{0} / v_{1}\right)$ and the indirect viral attenuation index $\left(r_{1} / r_{0}\right)$.

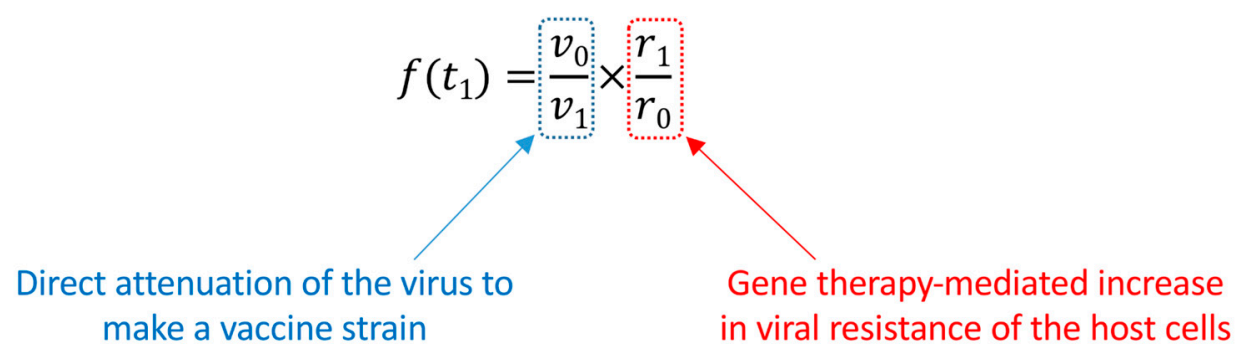

Figure 4. The concept of relative viral attenuation. (a) A schema describing direct and indirect viral attenuation. HIV usually infects host $\mathrm{CD}^{+}$cells efficiently and replicates rapidly. As a result, the host immune system fails to control viral replication (left). However, accumulating evidence in macaque AIDS models suggests that a live-attenuated virus, which infects and replicates slowly because of partial defects in the viral genome, can be controlled by the immune system and helps in further immunization against a potential superinfection with immunodeficiency virus strains that are homologous to the vaccine strain (upper right). The live attenuation method cannot be directly applied to HIV infection in humans because of safety concerns. However, indirect viral attenuation can be achieved by rendering the host cells HIV-resistant by an "intracellular immunization" gene therapy (lower right); (b) The definition of relative viral attenuation. This idea can connect live-attenuated vaccine studies and gene therapy approaches to achieve a functional cure. While live-attenuated HIV vaccines are not testable in humans for safety concerns, functional-cure gene therapy could be an alternative. 


\section{Gene Therapy Strategies against HIV}

The Berlin patient, an HIV-positive male United States citizen who was diagnosed with HIV while attending university in Berlin and later suffered from acute myelogenous leukemia, received a transplantation of allogeneic hematopoietic stem cells homozygous for CCR5- $\Delta 32$. This resulted in a subsequent functional HIV cure [71,72]. Because CCR5 is critical in HIV infection and transmission, as observed with CCR5- $\Delta 32$ homozygous cells resistant to HIV infection [84], the manipulation of CCR5 expression on HIV target cells has been intensively investigated and is considered to be effective [34,35,37,39,40,85-102]. CCR5 can be targeted by zinc finger nucleases [103,104], ribozymes [105], CRISPR/Cas9 methods [106], transcription activator-like effector nucleases [106] and shRNAs $[86,107,108]$. Among these, several gene therapy methods, including one using lentiviral vector LVsh5/C46 that expresses shRNA against CCR5 and HIV-1 entry inhibitor C46 [109] have been tested in clinical trials [93]. While CCR5 is involved in numerous pathologic states, including inflammatory and infectious diseases [110], a complete knockout of CCR5 can be related to an increased sensitivity to some viral infections [111,112]. Therefore, CCR5 gene editing should only be considered for an HIV cure [110].

The targeting of HIV RNA sequences by ribozymes or RNAs [44,99,113-123] and HIV DNA sequences by the CRISPR/Cas9 system [124] has been investigated and is also considered a major strategy $[100,125]$. The latter method has recently been of great interest, which is primarily because of its potential for targeting and disrupting integrated HIV DNA sequences to achieve a complete cure. A recent study targeted and inactivated the HIV-1 long terminal repeat (LTR) U3 region in vitro by Cas9 and guide RNAs (gRNAs), with no off-target gene editing to the host cells being detected [126]. Another study also successfully targeted the HIV-1 LTR U3 region using the CRISPR/Cas9 system. However, this study also detected the emergence of escape variant viruses mediated by the error-prone non-homologous end joining (NHEJ) DNA repair following the CRISPR/Cas9 targeting in the host cells [127]. The mutagenesis problem with CRISPR/Cas9 has also been observed in the treatments of other diseases [128] but can be a serious problem when targeting the HIV DNAs because the strategy might require sustained expression of Cas9 and gRNA in the potential HIV target cells, which means a sustained risk of mutagenesis [129]. Therefore, an improved method for disrupting HIV DNA while prohibiting the emergence of replication-competent escape variants caused by the NHEJ repair system might be necessary. Nevertheless, radical approaches can still be tested in cultured cells and animals. For example, a recent study demonstrated that the in vivo gene delivery of multiplex single-gRNAs and Staphylococcus aureus Cas9 to transgenic mice bearing HIV DNA using an adeno-associated virus (AAV) vector resulted in an efficient excision of HIV DNA in various tissues and organs [130]. If safety concerns are met, such a gene delivery method can be a powerful tool to achieve the systemic elimination of latent viral reservoirs in hematopoietic cells and nonhematopoietic cells, such as astrocytes [131]. Wang et al. (2018) have written a thorough review of topics regarding the targeting of HIV DNA by CRISPR/Cas9 [124].

An alternative to the CRISPR/Cas9 strategy is the silencing approach, which aims to reduce the production rate of HIV viral particles per integrated HIV DNA copy [68]. Lentiviral gene delivery enables RNA-based gene silencing, including the previously characterized small interfering RNA (siRNA) called PromA [30,132]. PromA is a short RNA sequence specific for the two NF-kB binding sites in the HIV LTR U3 region. While specific mRNA cleavage by post-transcriptional gene silencing is the best-known mechanism for siRNAs, PromA triggers TGS, which is mediated by epigenetic changes, such as DNA methylation and heterochromatin formation [116,133]. In fact, PromA has been shown to induce chromatin compaction in the HIV-1 promoter region [133]. This means that in contrast to methods attempting to eradicate HIV DNA, PromA locks and stabilizes the latently infecting HIV provirus and prevents the reactivation of viral reservoirs from stimuli, such as tissue necrosis factor (Figure 2) [31,134,135]. The efficacy of PromA in suppressing HIV-1 replication in vivo was first demonstrated by an HIV challenge study using humanized NOD/SCID/JAK3 ${ }^{\text {null }}$ (NOJ) mice transplanted with human peripheral mononuclear cells expressing shPromA [135]. Our recent 
study to extend the results using NOJ mice engrafted with shPromA-transduced CD34 ${ }^{+}$cells and their derivatives further demonstrated that PromA could be an effective gene therapy for protecting bone marrow CD34 ${ }^{+}$cells and the hematopoietic potential of the host from HIV infection (Figure 3) [26].

Other potential gene therapy methods include the secretion of soluble HIV entry inhibitors [38]; the rescue of hematopoiesis, including myelopoiesis, erythropoiesis and megakaryopoiesis using c-mpl [136]; the expression of a chimeric human-simian TRIM5 $\alpha$ [137]; the expression of p68 kinase [138]; and the expression of HIV Gag mutants [36].

\section{Application of Gene Therapy Methods to Immunotherapies}

This section sheds lights on a different application of gene therapy methods to fight against HIV. Immunotherapy approaches based on gene therapy methods have been extensively investigated. Chimeric antigen receptor (CAR) $\mathrm{T}$ cells are engineered $\mathrm{T}$ cells expressing CARs for the recognition and killing of target cells $[139,140]$. Most typical CARs are engineered to recognize an antigen with a monoclonal antibody-derived extracellular domain that is conjugated to T-cell receptor-derived transmembrane and intracellular domains. Therefore, despite the use of T-cell signaling pathways, such CAR T-cell therapies might be regarded as an enhancement of antibody-based therapies [141,142]. To date, most successful CAR T-cell therapies have been against cancers [143]. For example, the high efficacy of the adoptive transfer of CAR T cells recognizing CD19 has been demonstrated for the treatment of patients with B-cell acute lymphoblastic leukemia [144] and diffuse large B-cell lymphoma [145]. In contrast, CAR T-cell therapies may require the manufacture of autologous CAR T cells for each patient and thus are not yet widely available [145]. Several broadly neutralizing antibodies have been considered for generating CAR T cells against HIV infection [146-148]. Despite the shared concern of escape mutations with antibody-based therapies, CAR T cells are MHC-independent and more potent than the administration of neutralizing antibodies so better outcomes can be expected. A further improvement of HIV CAR gene therapy has been tested to make CAR T cells HIV-resistant by the insertion of the HIV CAR gene expression cassette into the CCR5 locus, which results in the disruption of CCR5 [148]. Finally, an adoptive transfer therapy using autologous CD34 ${ }^{+}$cells transduced with lentivirus expressing a CD4-based CAR that is able to bind the HIV envelope protein has been tested in humanized mice infected with HIV-1 [149] and pigtail macaques infected with a SHIV [150].

Another exciting gene transfer-based immunotherapy involves programming the production of specific anti-HIV antibodies [151,152]. Compared with vaccination, passive immunization using a set of broadly neutralizing antibodies is customizable, MHC-independent and provides instant and reliable protection against HIV [153,154]. However, neutralizing antibodies need repeated administration to provide prolonged protection [154]. Thus, the concept of antibody gene transfer is to overcome the limitation of passive immunization, which is only transiently effective [155]. It was demonstrated in a humanized mouse model that antibody gene transfer by intramuscular inoculation of an AAV vector encoding a full-length antibody was able to induce the production of the antibody by muscle cells and confer protection against intravenous HIV-1 challenge [156]. In another study, an adenovirus serotype 5 (Ad5) vector encoding an HIV-1-specific broadly neutralizing antibody PGT121 (Ad5.PGT121) afforded a more rapid and robust antibody response than an AAV encoding PGT121 (AAV1.PGT121) in HIV-1-infected bone marrow-liver-thymus humanized mice [157].

\section{Biosafety and Bioethics Concerns Regarding the Application of Anti-HIV Gene Therapies to Human Germline Cells for Pregnancy}

In the last part of the review, I would like to comment on the recent issue raised against anti-HIV gene therapy. In late 2018, it was reported that a Chinese researcher used the CRISPR/Cas9 technology to create twins bearing CCR5 double knockouts to confer HIV resistance [158]. However, the inheritable gene modification of human germline cells culminating in human pregnancy is currently unacceptable [159]. If applied to germline cells, CRISPR/Cas9 could cause additional inheritable 
mutations in the host genome DNA [128,160-162] and the influence of this is not entirely predictable at this moment. Therefore, such an investigation on human germline cells should be limited to nonclinical (i.e., in vitro) studies. Regarding the targeted gene, it should be emphasized that CCR5 knockout has not been proven to be safe. Even if a small population of people, mostly of Caucasian origin, is living without functional CCR5 alleles, this does not mean that the loss of CCR5 is universally harmless. This is partly because CCR5 has been reported to play important roles in some viral infections [111,112]. Moreover, there is an unexcluded possibility that the lack of CCR5 function among those carrying the CCR5- $\Delta 32 / \Delta 32$ double mutations could be compensated by accompanying genetic variations that do not exist in the majority of human populations with the wild-type CCR5 alleles. Regarding the protection from HIV-1 infection, CCR5-knockout individuals are still susceptible to the infection of CXCR4-tropic HIV-1 strains despite these risks. We refer to the statement published in 2017 by an American Society of Human Genetics workgroup regarding human germline genome editing [163].

\section{Conclusions}

The evidence suggests that the HIV infection alters the bone marrow hematopoietic potential of the host. This can lead to impaired $\mathrm{CD}^{+}{ }^{+} \mathrm{T}$-cell generation and contributes to the loss of peripheral $\mathrm{CD}^{+} \mathrm{T}$ cells and the manifestation of AIDS. Further investigations on the topics discussed in this review will collectively enhance our understanding of the important role that HIV gene therapy can contribute toward an HIV cure. Intracellular immunization gene therapies, including silencing approaches, are expected to confer relative viral attenuation without interfering with the HIV genome and assist cellular immunity to kill HIV-infected cells. This will ultimately lead to better viral control and a functional cure. In light of this, the long-term preservation of bone marrow CD $34^{+}$cells and hematopoietic potential as well as aviremic states and restored peripheral CD4 ${ }^{+} \mathrm{T}$-cell counts may be an appropriate endpoint of future anti-HIV gene therapies. With this regard, our recent in vivo study using humanized mice transplanted with shRNA (shPromA)-transduced CD $34^{+}$cells and challenged with HIV-1 has been described to show that the anti-HIV intracellular immunization gene therapy can indeed protect bone marrow HSPCs. Although the efficacy and safety of those novel gene therapy strategies need further improvements for the future applications to autologous HSPC transplantation of HIV-infected patients, a combination of a gene therapy and host immunization based on preserved bone marrow hematopoietic potential and relative viral attenuation will give a hope for a functional cure. Furthermore, the recent advances in gene therapy-based immunotherapy approaches against HIV have also been described in this review.

Funding: This work received no external funding.

Acknowledgments: I thank Enago (www.enago.jp) for the English language review.

Conflicts of Interest: The author declares no conflict of interest.

\section{References}

1. McMichael, A.J. Is a Human CD8 T-Cell Vaccine Possible, and if So, What Would It Take? Could a CD8(+) T-Cell Vaccine Prevent Persistent HIV Infection? Cold Spring Harb. Perspect. Biol. 2018, 10. [CrossRef] [PubMed]

2. UNAIDS. UNAIDS Data 2018; UNAIDS: Geneva, Switzerland, 2018.

3. Hong, F.F.; Mellors, J.W. Changes in HIV reservoirs during long-term antiretroviral therapy. Curr. Opin. HIV AIDS 2015, 10, 43-48. [CrossRef] [PubMed]

4. Ghosn, J.; Taiwo, B.; Seedat, S.; Autran, B.; Katlama, C. HIV. Lancet 2018, 392, 685-697. [CrossRef]

5. Zou, W.; Denton, P.W.; Watkins, R.L.; Krisko, J.F.; Nochi, T.; Foster, J.L.; Garcia, J.V. Nef functions in BLT mice to enhance HIV-1 replication and deplete CD4+CD8+ thymocytes. Retrovirology 2012, 9, 44. [CrossRef] [PubMed]

6. Meissner, E.G.; Duus, K.M.; Loomis, R.; D'Agostin, R.; Su, L. HIV-1 replication and pathogenesis in the human thymus. Curr. HIV Res. 2003, 1, 275-285. [CrossRef] [PubMed] 
7. Zaitseva, M.B.; Lee, S.; Rabin, R.L.; Tiffany, H.L.; Farber, J.M.; Peden, K.W.; Murphy, P.M.; Golding, H. CXCR4 and CCR5 on human thymocytes: Biological function and role in HIV-1 infection. J. Immunol. 1998, 161, 3103-3113. [PubMed]

8. Taylor, J.R., Jr.; Kimbrell, K.C.; Scoggins, R.; Delaney, M.; Wu, L.; Camerini, D. Expression and function of chemokine receptors on human thymocytes: Implications for infection by human immunodeficiency virus type 1. J. Virol. 2001, 75, 8752-8760. [CrossRef] [PubMed]

9. Parinitha, S.; Kulkarni, M. Haematological changes in HIV infection with correlation to CD4 cell count. Australas. Med. J. 2012, 5, 157-162. [CrossRef] [PubMed]

10. Marandin, A.; Katz, A.; Oksenhendler, E.; Tulliez, M.; Picard, F.; Vainchenker, W.; Louache, F. Loss of primitive hematopoietic progenitors in patients with human immunodeficiency virus infection. Blood 1996, 88, 4568-4578. [PubMed]

11. Re, A.; Cattaneo, C.; Skert, C.; Balsalobre, P.; Michieli, M.; Bower, M.; Ferreri, A.J.; Hentrich, M.; Ribera, J.M.; Allione, B.; et al. Stem cell mobilization in HIV seropositive patients with lymphoma. Haematologica 2013, 98, 1762-1768. [CrossRef] [PubMed]

12. Schooley, R.T.; Mladenovic, J.; Sevin, A.; Chiu, S.; Miles, S.A.; Pomerantz, R.J.; Campbell, T.B.; Bell, D.; Ambruso, D.; Wong, R.; et al. Reduced mobilization of CD34+ stem cells in advanced human immunodeficiency virus type 1 disease. J. Infect. Dis. 2000, 181, 148-157. [CrossRef] [PubMed]

13. Nielsen, S.D.; Clark, D.R.; Hutchings, M.; Dam-Larsen, S.; Repping, S.; Nielsen, J.O.; Mathiesen, L.; Miedema, F.; Hansen, J.E. Treatment with granulocyte colony-stimulating factor decreases the capacity of hematopoietic progenitor cells for generation of lymphocytes in human immunodeficiency virus-infected persons. J. Infect. Dis. 1999, 180, 1819-1826. [CrossRef] [PubMed]

14. Sauce, D.; Larsen, M.; Fastenackels, S.; Pauchard, M.; Ait-Mohand, H.; Schneider, L.; Guihot, A.; Boufassa, F.; Zaunders, J.; Iguertsira, M.; et al. HIV disease progression despite suppression of viral replication is associated with exhaustion of lymphopoiesis. Blood 2011, 117, 5142-5151. [CrossRef] [PubMed]

15. Koka, P.S.; Kitchen, C.M.; Reddy, S.T. Targeting c-Mpl for revival of human immunodeficiency virus type 1-induced hematopoietic inhibition when CD34+ progenitor cells are re-engrafted into a fresh stromal microenvironment in vivo. J. Virol. 2004, 78, 11385-11392. [CrossRef] [PubMed]

16. Ikegawa, M.; Yuan, J.; Matsumoto, K.; Herrmann, S.; Iwamoto, A.; Nakamura, T.; Matsushita, S.; Kimura, T.; Honjo, T.; Tashiro, K. Elevated plasma stromal cell-derived factor 1 protein level in the progression of HIV type 1 infection/AIDS. AIDS Res. Hum. Retroviruses 2001, 17, 587-595. [CrossRef] [PubMed]

17. Bordoni, V.; Bibas, M.; Viola, D.; Sacchi, A.; Cimini, E.; Tumino, N.; Casetti, R.; Amendola, A.; Ammassari, A.; Agrati, C.; et al. Bone Marrow CD34(+) Progenitor Cells from HIV-Infected Patients Show an Impaired T Cell Differentiation Potential Related to Proinflammatory Cytokines. AIDS Res. Hum. Retroviruses 2017, 33 , 590-596. [CrossRef] [PubMed]

18. Isgro, A.; Mezzaroma, I.; Aiuti, A.; Fantauzzi, A.; Pinti, M.; Cossarizza, A.; Aiuti, F. Decreased apoptosis of bone marrow progenitor cells in HIV-1-infected patients during highly active antiretroviral therapy. AIDS 2004, 18, 1335-1337. [CrossRef] [PubMed]

19. Fischer, K.D.; Agrawal, D.K. Hematopoietic stem and progenitor cells in inflammation and allergy. Front. Immunol. 2013, 4, 428. [CrossRef] [PubMed]

20. Luis, T.C.; Tremblay, C.S.; Manz, M.G.; North, T.E.; King, K.Y.; Challen, G.A. Inflammatory signals in HSPC development and homeostasis: Too much of a good thing? Exp. Hematol. 2016, 44, 908-912. [CrossRef] [PubMed]

21. Bozzano, F.; Marras, F.; Ascierto, M.L.; Cantoni, C.; Cenderello, G.; Dentone, C.; Di Biagio, A.; Orofino, G.; Mantia, E.; Boni, S.; et al. 'Emergency exit' of bone-marrow-resident CD34(+)DNAM-1(bright)CXCR4(+)-committed lymphoid precursors during chronic infection and inflammation. Nat. Commun. 2015, 6, 8109. [CrossRef] [PubMed]

22. Koka, P.S.; Fraser, J.K.; Bryson, Y.; Bristol, G.C.; Aldrovandi, G.M.; Daar, E.S.; Zack, J.A. Human immunodeficiency virus inhibits multilineage hematopoiesis in vivo. J. Virol. 1998, 72, 5121-5127. [PubMed]

23. Jenkins, M.; Hanley, M.B.; Moreno, M.B.; Wieder, E.; McCune, J.M. Human immunodeficiency virus-1 infection interrupts thymopoiesis and multilineage hematopoiesis in vivo. Blood 1998, 91, 2672-2678. [PubMed]

24. Arainga, M.; Su, H.; Poluektova, L.Y.; Gorantla, S.; Gendelman, H.E. HIV-1 cellular and tissue replication patterns in infected humanized mice. Sci. Rep. 2016, 6, 23513. [CrossRef] [PubMed] 
25. Li, G.; Zhao, J.; Cheng, L.; Jiang, Q.; Kan, S.; Qin, E.; Tu, B.; Zhang, X.; Zhang, L.; Su, L.; et al. HIV-1 infection depletes human CD34+CD38- hematopoietic progenitor cells via pDC-dependent mechanisms. PLoS Pathog. 2017, 13, e1006505. [CrossRef] [PubMed]

26. Tsukamoto, $\mathrm{T}$. Transcriptional gene silencing limits CXCR4-associated depletion of bone marrow CD34+ cells in HIV-1 infection. AIDS 2018, 32, 1737-1747; Erratum in 2018, 32, 2857-2858. [CrossRef] [PubMed]

27. Tsukamoto, T. HIV Impacts CD34+ Progenitors Involved in T-Cell Differentiation During Coculture With Mouse Stromal OP9-DL1 Cells. Front. Immunol. 2019, 10, 81. [CrossRef] [PubMed]

28. Baltimore, D. Gene therapy. Intracellular immunization. Nature 1988, 335, 395-396. [CrossRef] [PubMed]

29. Tsukamoto, T.; Yamamoto, H.; Okada, S.; Matano, T. Recursion-based depletion of human immunodeficiency virus-specific naive CD4(+) T cells may facilitate persistent viral replication and chronic viraemia leading to acquired immunodeficiency syndrome. Med. Hypotheses 2016, 94, 81-85. [CrossRef] [PubMed]

30. Klemm, V.; Mitchell, J.; Cortez-Jugo, C.; Cavalieri, F.; Symonds, G.; Caruso, F.; Kelleher, A.D.; Ahlenstiel, C. Achieving HIV-1 Control through RNA-Directed Gene Regulation. Genes 2016, 7, 119. [CrossRef] [PubMed]

31. Mendez, C.; Ledger, S.; Petoumenos, K.; Ahlenstiel, C.; Kelleher, A.D. RNA-induced epigenetic silencing inhibits HIV-1 reactivation from latency. Retrovirology 2018, 15, 67. [CrossRef] [PubMed]

32. Savkovic, B.; Nichols, J.; Birkett, D.; Applegate, T.; Ledger, S.; Symonds, G.; Murray, J.M. A quantitative comparison of anti-HIV gene therapy delivered to hematopoietic stem cells versus CD4+ $\mathrm{T}$ cells. PLoS Comput. Biol. 2014, 10, e1003681. [CrossRef] [PubMed]

33. Kitchen, S.G.; Shimizu, S.; An, D.S. Stem cell-based anti-HIV gene therapy. Virology 2011, 411, $260-272$. [CrossRef] [PubMed]

34. Chattong, S.; Chaikomon, K.; Chaiya, T.; Tangkosakul, T.; Palavutitotai, N.; Anusornvongchai, T.; Manotham, K. Efficient ZFN-Mediated Stop Codon Integration into the CCR5 Locus in Hematopoietic Stem Cells: A Possible Source for Intrabone Marrow Cell Transplantation. AIDS Res. Hum. Retroviruses 2018. [CrossRef] [PubMed]

35. Li, L.; Krymskaya, L.; Wang, J.; Henley, J.; Rao, A.; Cao, L.F.; Tran, C.A.; Torres-Coronado, M.; Gardner, A.; Gonzalez, N.; et al. Genomic editing of the HIV-1 coreceptor CCR5 in adult hematopoietic stem and progenitor cells using zinc finger nucleases. Mol. Ther. 2013, 21, 1259-1269. [CrossRef] [PubMed]

36. Joshi, A.; Garg, H.; Ablan, S.; Freed, E.O.; Nagashima, K.; Manjunath, N.; Shankar, P. Targeting the HIV entry, assembly and release pathways for anti-HIV gene therapy. Virology 2011, 415, 95-106. [CrossRef] [PubMed]

37. Khamaikawin, W.; Shimizu, S.; Kamata, M.; Cortado, R.; Jung, Y.; Lam, J.; Wen, J.; Kim, P.; Xie, Y.; Kim, S.; et al. Modeling Anti-HIV-1 HSPC-Based Gene Therapy in Humanized Mice Previously Infected with HIV-1. Mol. Ther. Methods Clin. Dev. 2018, 9, 23-32. [CrossRef] [PubMed]

38. Falkenhagen, A.; Singh, J.; Asad, S.; Leontyev, D.; Read, S.; Zuniga-Pflucker, J.C.; Joshi, S. Control of HIV Infection In Vivo Using Gene Therapy with a Secreted Entry Inhibitor. Mol. Ther. Nucleic Acids 2017, 9 , 132-144. [CrossRef] [PubMed]

39. Petit, N.Y.; Baillou, C.; Burlion, A.; Dorgham, K.; Levacher, B.; Amiel, C.; Schneider, V.; Lemoine, F.M.; Gorochov, G.; Marodon, G. Gene transfer of two entry inhibitors protects CD4(+) T cell from HIV-1 infection in humanized mice. Gene Ther. 2016, 23, 144-150. [CrossRef] [PubMed]

40. Myburgh, R.; Ivic, S.; Pepper, M.S.; Gers-Huber, G.; Li, D.; Audige, A.; Rochat, M.A.; Jaquet, V.; Regenass, S.; Manz, M.G.; et al. Lentivector Knockdown of CCR5 in Hematopoietic Stem and Progenitor Cells Confers Functional and Persistent HIV-1 Resistance in Humanized Mice. J. Virol. 2015, 89, 6761-6772. [CrossRef] [PubMed]

41. Rosenzweig, M.; Marks, D.F.; Hempel, D.; Heusch, M.; Kraus, G.; Wong-Staal, F.; Johnson, R.P. Intracellular immunization of rhesus CD34+ hematopoietic progenitor cells with a hairpin ribozyme protects T cells and macrophages from simian immunodeficiency virus infection. Blood 1997, 90, 4822-4831. [PubMed]

42. An, D.S.; Donahue, R.E.; Kamata, M.; Poon, B.; Metzger, M.; Mao, S.H.; Bonifacino, A.; Krouse, A.E.; Darlix, J.L.; Baltimore, D.; et al. Stable reduction of CCR5 by RNAi through hematopoietic stem cell transplant in non-human primates. Proc. Natl. Acad. Sci. USA 2007, 104, 13110-13115. [CrossRef] [PubMed]

43. DiGiusto, D.L.; Krishnan, A.; Li, L.; Li, H.; Li, S.; Rao, A.; Mi, S.; Yam, P.; Stinson, S.; Kalos, M.; et al. RNA-based gene therapy for HIV with lentiviral vector-modified CD34(+) cells in patients undergoing transplantation for AIDS-related lymphoma. Sci. Transl. Med. 2010, 2, 36ra43. [CrossRef] [PubMed] 
44. Mitsuyasu, R.T.; Merigan, T.C.; Carr, A.; Zack, J.A.; Winters, M.A.; Workman, C.; Bloch, M.; Lalezari, J.; Becker, S.; Thornton, L.; et al. Phase 2 gene therapy trial of an anti-HIV ribozyme in autologous CD34+ cells. Nat. Med. 2009, 15, 285-292. [CrossRef] [PubMed]

45. Podsakoff, G.M.; Engel, B.C.; Carbonaro, D.A.; Choi, C.; Smogorzewska, E.M.; Bauer, G.; Selander, D.; Csik, S.; Wilson, K.; Betts, M.R.; et al. Selective survival of peripheral blood lymphocytes in children with HIV-1 following delivery of an anti-HIV gene to bone marrow CD34(+) cells. Mol. Ther. 2005, 12, 77-86. [CrossRef] [PubMed]

46. Aiuti, A.; Cattaneo, F.; Galimberti, S.; Benninghoff, U.; Cassani, B.; Callegaro, L.; Scaramuzza, S.; Andolfi, G.; Mirolo, M.; Brigida, I.; et al. Gene therapy for immunodeficiency due to adenosine deaminase deficiency. N. Engl. J. Med. 2009, 360, 447-458. [CrossRef] [PubMed]

47. Boztug, K.; Schmidt, M.; Schwarzer, A.; Banerjee, P.P.; Diez, I.A.; Dewey, R.A.; Bohm, M.; Nowrouzi, A.; Ball, C.R.; Glimm, H.; et al. Stem-cell gene therapy for the Wiskott-Aldrich syndrome. N. Engl. J. Med. 2010, 363, 1918-1927. [CrossRef] [PubMed]

48. Hacein-Bey-Abina, S.; Hauer, J.; Lim, A.; Picard, C.; Wang, G.P.; Berry, C.C.; Martinache, C.; Rieux-Laucat, F.; Latour, S.; Belohradsky, B.H.; et al. Efficacy of gene therapy for X-linked severe combined immunodeficiency. N. Engl. J. Med. 2010, 363, 355-364. [CrossRef] [PubMed]

49. De Ravin, S.S.; Wu, X.; Moir, S.; Anaya-O'Brien, S.; Kwatemaa, N.; Littel, P.; Theobald, N.; Choi, U.; $\mathrm{Su}, \mathrm{L}$.; Marquesen, M.; et al. Lentiviral hematopoietic stem cell gene therapy for X-linked severe combined immunodeficiency. Sci. Transl. Med. 2016, 8, 335ra357. [CrossRef] [PubMed]

50. Uchida, N.; Sutton, R.E.; Friera, A.M.; He, D.; Reitsma, M.J.; Chang, W.C.; Veres, G.; Scollay, R.; Weissman, I.L. $\mathrm{HIV}$, but not murine leukemia virus, vectors mediate high efficiency gene transfer into freshly isolated G0/G1 human hematopoietic stem cells. Proc. Natl. Acad. Sci. USA 1998, 95, 11939-11944. [CrossRef] [PubMed]

51. Cattoglio, C.; Pellin, D.; Rizzi, E.; Maruggi, G.; Corti, G.; Miselli, F.; Sartori, D.; Guffanti, A.; Di Serio, C.; Ambrosi, A.; et al. High-definition mapping of retroviral integration sites identifies active regulatory elements in human multipotent hematopoietic progenitors. Blood 2010, 116, 5507-5517. [CrossRef] [PubMed]

52. Piras, F.; Riba, M.; Petrillo, C.; Lazarevic, D.; Cuccovillo, I.; Bartolaccini, S.; Stupka, E.; Gentner, B.; Cittaro, D.; Naldini, L.; et al. Lentiviral vectors escape innate sensing but trigger p53 in human hematopoietic stem and progenitor cells. EMBO Mol. Med. 2017, 9, 1198-1211. [CrossRef] [PubMed]

53. Yu, S.F.; von Ruden, T.; Kantoff, P.W.; Garber, C.; Seiberg, M.; Ruther, U.; Anderson, W.F.; Wagner, E.F.; Gilboa, E. Self-inactivating retroviral vectors designed for transfer of whole genes into mammalian cells. Proc. Natl. Acad. Sci. USA 1986, 83, 3194-3198. [CrossRef] [PubMed]

54. Scala, S.; Basso-Ricci, L.; Dionisio, F.; Pellin, D.; Giannelli, S.; Salerio, F.A.; Leonardelli, L.; Cicalese, M.P.; Ferrua, F.; Aiuti, A.; et al. Dynamics of genetically engineered hematopoietic stem and progenitor cells after autologous transplantation in humans. Nat. Med. 2018, 24, 1683-1690. [CrossRef] [PubMed]

55. Nasimuzzaman, M.; Lynn, D.; Ernst, R.; Beuerlein, M.; Smith, R.H.; Shrestha, A.; Cross, S.; Link, K.; Lutzko, C.; Nordling, D.; et al. Production and purification of high-titer foamy virus vector for the treatment of leukocyte adhesion deficiency. Mol. Ther. Methods Clin. Dev. 2016, 3, 16004. [CrossRef] [PubMed]

56. Vanhee, S.; Vandekerckhove, B. Pluripotent stem cell based gene therapy for hematological diseases. Crit. Rev. Oncol. Hematol. 2016, 97, 238-246. [CrossRef] [PubMed]

57. Li, Y.; Chan, L.; Nguyen, H.V.; Tsang, S.H. Personalized Medicine: Cell and Gene Therapy Based on Patient-Specific iPSC-Derived Retinal Pigment Epithelium Cells. Adv. Exp. Med. Biol. 2016, 854, 549-555. [CrossRef] [PubMed]

58. Ou, Z.; Niu, X.; He, W.; Chen, Y.; Song, B.; Xian, Y.; Fan, D.; Tang, D.; Sun, X. The Combination of CRISPR/Cas9 and iPSC Technologies in the Gene Therapy of Human beta-thalassemia in Mice. Sci. Rep. 2016, 6, 32463. [CrossRef] [PubMed]

59. Carpenter, L.; Malladi, R.; Yang, C.T.; French, A.; Pilkington, K.J.; Forsey, R.W.; Sloane-Stanley, J.; Silk, K.M.; Davies, T.J.; Fairchild, P.J.; et al. Human induced pluripotent stem cells are capable of B-cell lymphopoiesis. Blood 2011, 117, 4008-4011. [CrossRef] [PubMed]

60. Higaki, K.; Hirao, M.; Kawana-Tachikawa, A.; Iriguchi, S.; Kumagai, A.; Ueda, N.; Bo, W.; Kamibayashi, S.; Watanabe, A.; Nakauchi, H.; et al. Generation of HIV-Resistant Macrophages from IPSCs by Using Transcriptional Gene Silencing and Promoter-Targeted RNA. Mol. Ther. Nucleic Acids 2018, 12, 793-804. [CrossRef] [PubMed] 
61. Nishimura, T.; Kaneko, S.; Kawana-Tachikawa, A.; Tajima, Y.; Goto, H.; Zhu, D.; Nakayama-Hosoya, K.; Iriguchi, S.; Uemura, Y.; Shimizu, T.; et al. Generation of rejuvenated antigen-specific T cells by reprogramming to pluripotency and redifferentiation. Cell Stem Cell 2013, 12, 114-126. [CrossRef] [PubMed]

62. Huyghe, J.; Magdalena, S.; Vandekerckhove, L. Fight fire with fire: Gene therapy strategies to cure HIV. Expert Rev. Anti Infect. Ther. 2017, 15, 747-758. [CrossRef] [PubMed]

63. Deeks, S.G. HIV: Shock and kill. Nature 2012, 487, 439-440. [CrossRef] [PubMed]

64. Darcis, G.; Kula, A.; Bouchat, S.; Fujinaga, K.; Corazza, F.; Ait-Ammar, A.; Delacourt, N.; Melard, A.; Kabeya, K.; Vanhulle, C.; et al. An In-Depth Comparison of Latency-Reversing Agent Combinations in Various In Vitro and Ex Vivo HIV-1 Latency Models Identified Bryostatin-1+JQ1 and Ingenol-B+JQ1 to Potently Reactivate Viral Gene Expression. PLoS Pathog. 2015, 11, e1005063. [CrossRef] [PubMed]

65. Archin, N.M.; Liberty, A.L.; Kashuba, A.D.; Choudhary, S.K.; Kuruc, J.D.; Crooks, A.M.; Parker, D.C.; Anderson, E.M.; Kearney, M.F.; Strain, M.C.; et al. Administration of vorinostat disrupts HIV-1 latency in patients on antiretroviral therapy. Nature 2012, 487, 482-485. [CrossRef] [PubMed]

66. Elliott, J.H.; Wightman, F.; Solomon, A.; Ghneim, K.; Ahlers, J.; Cameron, M.J.; Smith, M.Z.; Spelman, T.; McMahon, J.; Velayudham, P.; et al. Activation of HIV transcription with short-course vorinostat in HIV-infected patients on suppressive antiretroviral therapy. PLoS Pathog. 2014, 10, e1004473. [CrossRef] [PubMed]

67. Rasmussen, T.A.; Tolstrup, M.; Brinkmann, C.R.; Olesen, R.; Erikstrup, C.; Solomon, A.; Winckelmann, A.; Palmer, S.; Dinarello, C.; Buzon, M.; et al. Panobinostat, a histone deacetylase inhibitor, for latent-virus reactivation in HIV-infected patients on suppressive antiretroviral therapy: A phase 1/2, single group, clinical trial. Lancet HIV 2014, 1, e13-e21. [CrossRef]

68. Cary, D.C.; Peterlin, B.M. Targeting the latent reservoir to achieve functional HIV cure. F1000Research 2016, 5, F1000. [CrossRef] [PubMed]

69. Chen, T.; Hudnall, S.D. Anatomical mapping of human herpesvirus reservoirs of infection. Mod. Pathol. 2006, 19, 726-737. [CrossRef] [PubMed]

70. Sengupta, S.; Siliciano, R.F. Targeting the Latent Reservoir for HIV-1. Immunity 2018, 48, 872-895. [CrossRef] [PubMed]

71. Hutter, G.; Nowak, D.; Mossner, M.; Ganepola, S.; Mussig, A.; Allers, K.; Schneider, T.; Hofmann, J.; Kucherer, C.; Blau, O.; et al. Long-term control of HIV by CCR5 Delta32/Delta32 stem-cell transplantation. N. Engl. J. Med. 2009, 360, 692-698. [CrossRef] [PubMed]

72. Allers, K.; Hutter, G.; Hofmann, J.; Loddenkemper, C.; Rieger, K.; Thiel, E.; Schneider, T. Evidence for the cure of HIV infection by CCR5Delta32/Delta32 stem cell transplantation. Blood 2011, 117, 2791-2799. [CrossRef] [PubMed]

73. Archin, N.M.; Margolis, D.M. Emerging strategies to deplete the HIV reservoir. Curr. Opin. Infect. Dis. 2014, 27, 29-35. [CrossRef] [PubMed]

74. Berzofsky, J.A.; Ahlers, J.D.; Janik, J.; Morris, J.; Oh, S.; Terabe, M.; Belyakov, I.M. Progress on new vaccine strategies against chronic viral infections. J. Clin. Invest. 2004, 114, 450-462. [CrossRef] [PubMed]

75. Noto, A.; Trautmann, L. Developing Combined HIV Vaccine Strategies for a Functional Cure. Vaccines 2013, 1, 481-496. [CrossRef] [PubMed]

76. Reeves, R.K.; Gillis, J.; Wong, F.E.; Johnson, R.P. Vaccination with SIVmac239Deltanef activates CD4+ T cells in the absence of CD4 T-cell loss. J. Med. Primatol. 2009, 38 (Suppl. 1), 8-16. [CrossRef]

77. Whitney, J.B.; Ruprecht, R.M. Live attenuated HIV vaccines: Pitfalls and prospects. Curr. Opin. Infect. Dis. 2004, 17, 17-26. [CrossRef] [PubMed]

78. Sutton, M.S.; Burns, C.M.; Weiler, A.M.; Balgeman, A.J.; Braasch, A.; Lehrer-Brey, G.; Friedrich, T.C.; O'Connor, S.L. Vaccination with Live Attenuated Simian Immunodeficiency Virus (SIV) Protects from Mucosal, but Not Necessarily Intravenous, Challenge with a Minimally Heterologous SIV. J. Virol. 2016, 90, 5541-5548. [CrossRef] [PubMed]

79. Abel, K.; Compton, L.; Rourke, T.; Montefiori, D.; Lu, D.; Rothaeusler, K.; Fritts, L.; Bost, K.; Miller, C.J. Simian-human immunodeficiency virus SHIV89.6-induced protection against intravaginal challenge with pathogenic SIVmac239 is independent of the route of immunization and is associated with a combination of cytotoxic T-lymphocyte and alpha interferon responses. J. Virol. 2003, 77, 3099-3118. [PubMed] 
80. Nilsson, C.; Makitalo, B.; Thorstensson, R.; Norley, S.; Binninger-Schinzel, D.; Cranage, M.; Rud, E.; Biberfeld, G.; Putkonen, P. Live attenuated simian immunodeficiency virus (SIV)mac in macaques can induce protection against mucosal infection with SIVsm. AIDS 1998, 12, 2261-2270. [CrossRef] [PubMed]

81. Connor, R.I.; Montefiori, D.C.; Binley, J.M.; Moore, J.P.; Bonhoeffer, S.; Gettie, A.; Fenamore, E.A.; Sheridan, K.E.; Ho, D.D.; Dailey, P.J.; et al. Temporal analyses of virus replication, immune responses, and efficacy in rhesus macaques immunized with a live, attenuated simian immunodeficiency virus vaccine. J. Virol. 1998, 72, 7501-7509. [PubMed]

82. Sugimoto, C.; Watanabe, S.; Naruse, T.; Kajiwara, E.; Shiino, T.; Umano, N.; Ueda, K.; Sato, H.; Ohgimoto, S.; Hirsch, V.; et al. Protection of macaques with diverse MHC genotypes against a heterologous SIV by vaccination with a deglycosylated live-attenuated SIV. PLoS ONE 2010, 5, e11678. [CrossRef] [PubMed]

83. Tsukamoto, T.; Yamamoto, H.; Matano, T. CD8(+) Cytotoxic-T-Lymphocyte Breadth Could Facilitate Early Immune Detection of Immunodeficiency Virus-Derived Epitopes with Limited Expression Levels. mSphere 2019, 4. [CrossRef] [PubMed]

84. Duarte, R.F.; Salgado, M.; Sanchez-Ortega, I.; Arnan, M.; Canals, C.; Domingo-Domenech, E.; Fernandez-de-Sevilla, A.; Gonzalez-Barca, E.; Moron-Lopez, S.; Nogues, N.; et al. CCR5 Delta32 homozygous cord blood allogeneic transplantation in a patient with HIV: A case report. Lancet HIV 2015, 2, e236-e242. [CrossRef]

85. Xu, L.; Yang, H.; Gao, Y.; Chen, Z.; Xie, L.; Liu, Y.; Liu, Y.; Wang, X.; Li, H.; Lai, W.; et al. CRISPR/Cas9-Mediated CCR5 Ablation in Human Hematopoietic Stem/Progenitor Cells Confers HIV-1 Resistance In Vivo. Mol. Ther. 2017, 25, 1782-1789. [CrossRef] [PubMed]

86. Symonds, G.; Bartlett, J.S.; Kiem, H.P.; Tsie, M.; Breton, L. Cell-Delivered Entry Inhibitors for HIV-1: CCR5 Downregulation and Blocking Virus/Membrane Fusion in Defending the Host Cell Population. AIDS Patient Care STDS 2016, 30, 545-550. [CrossRef] [PubMed]

87. Shi, B.; Li, J.; Shi, X.; Jia, W.; Wen, Y.; Hu, X.; Zhuang, F.; Xi, J.; Zhang, L. TALEN-Mediated Knockout of CCR5 Confers Protection Against Infection of Human Immunodeficiency Virus. J. Acquir. Immune Defic. Syndr. 2017, 74, 229-241. [CrossRef] [PubMed]

88. Shimizu, S.; Yadav, S.S.; An, D.S. Stable Delivery of CCR5-Directed shRNA into Human Primary Peripheral Blood Mononuclear Cells and Hematopoietic Stem/Progenitor Cells via a Lentiviral Vector. Methods Mol. Biol. 2016, 1364, 235-248. [CrossRef] [PubMed]

89. Sather, B.D.; Romano Ibarra, G.S.; Sommer, K.; Curinga, G.; Hale, M.; Khan, I.F.; Singh, S.; Song, Y.; Gwiazda, K.; Sahni, J.; et al. Efficient modification of CCR5 in primary human hematopoietic cells using a megaTAL nuclease and AAV donor template. Sci. Transl. Med. 2015, 7, 307ra156. [CrossRef] [PubMed]

90. Saydaminova, K.; Ye, X.; Wang, H.; Richter, M.; Ho, M.; Chen, H.; Xu, N.; Kim, J.S.; Papapetrou, E.; Holmes, M.C.; et al. Efficient genome editing in hematopoietic stem cells with helper-dependent Ad5/35 vectors expressing site-specific endonucleases under microRNA regulation. Mol. Ther. Methods Clin. Dev. 2015, 1, 14057. [CrossRef] [PubMed]

91. Manotham, K.; Chattong, S.; Setpakdee, A. Generation of CCR5-defective CD34 cells from ZFN-driven stop codon-integrated mesenchymal stem cell clones. J. Biomed. Sci. 2015, 22, 25. [CrossRef] [PubMed]

92. Burke, B.P.; Levin, B.R.; Zhang, J.; Sahakyan, A.; Boyer, J.; Carroll, M.V.; Colon, J.C.; Keech, N.; Rezek, V.; Bristol, G.; et al. Engineering Cellular Resistance to HIV-1 Infection In Vivo Using a Dual Therapeutic Lentiviral Vector. Mol. Ther. Nucleic Acids 2015, 4, e236. [CrossRef] [PubMed]

93. Wolstein, O.; Boyd, M.; Millington, M.; Impey, H.; Boyer, J.; Howe, A.; Delebecque, F.; Cornetta, K.; Rothe, M.; Baum, C.; et al. Preclinical safety and efficacy of an anti-HIV-1 lentiviral vector containing a short hairpin RNA to CCR5 and the C46 fusion inhibitor. Mol. Ther. Methods Clin. Dev. 2014, 1, 11. [CrossRef] [PubMed]

94. Holt, N.; Wang, J.; Kim, K.; Friedman, G.; Wang, X.; Taupin, V.; Crooks, G.M.; Kohn, D.B.; Gregory, P.D.; Holmes, M.C.; et al. Human hematopoietic stem/progenitor cells modified by zinc-finger nucleases targeted to CCR5 control HIV-1 in vivo. Nat. Biotechnol. 2010, 28, 839-847. [CrossRef] [PubMed]

95. Liang, M.; Kamata, M.; Chen, K.N.; Pariente, N.; An, D.S.; Chen, I.S. Inhibition of HIV-1 infection by a unique short hairpin RNA to chemokine receptor 5 delivered into macrophages through hematopoietic progenitor cell transduction. J. Gene Med. 2010, 12, 255-265. [CrossRef] [PubMed]

96. Shimizu, S.; Hong, P.; Arumugam, B.; Pokomo, L.; Boyer, J.; Koizumi, N.; Kittipongdaja, P.; Chen, A.; Bristol, G.; Galic, Z.; et al. A highly efficient short hairpin RNA potently down-regulates CCR5 expression in systemic lymphoid organs in the hu-BLT mouse model. Blood 2010, 115, 1534-1544. [CrossRef] [PubMed] 
97. Anderson, J.S.; Javien, J.; Nolta, J.A.; Bauer, G. Preintegration HIV-1 inhibition by a combination lentiviral vector containing a chimeric TRIM5 alpha protein, a CCR5 shRNA, and a TAR decoy. Mol. Ther. 2009, 17, 2103-2114. [CrossRef] [PubMed]

98. Anderson, J.; Akkina, R. Complete knockdown of CCR5 by lentiviral vector-expressed siRNAs and protection of transgenic macrophages against HIV-1 infection. Gene Ther. 2007, 14, 1287-1297. [CrossRef] [PubMed]

99. Anderson, J.; Li, M.J.; Palmer, B.; Remling, L.; Li, S.; Yam, P.; Yee, J.K.; Rossi, J.; Zaia, J.; Akkina, R. Safety and Efficacy of a Lentiviral Vector Containing Three Anti-HIV Genes-CCR5 Ribozyme, Tat-rev siRNA, and TAR Decoy-in SCID-hu Mouse-Derived T Cells. Mol. Ther. 2007, 15, 1182-1188. [CrossRef] [PubMed]

100. Li, M.J.; Kim, J.; Li, S.; Zaia, J.; Yee, J.K.; Anderson, J.; Akkina, R.; Rossi, J.J. Long-term inhibition of HIV-1 infection in primary hematopoietic cells by lentiviral vector delivery of a triple combination of anti-HIV shRNA, anti-CCR5 ribozyme, and a nucleolar-localizing TAR decoy. Mol. Ther. 2005, 12, 900-909. [CrossRef] [PubMed]

101. Bai, J.; Rossi, J.; Akkina, R. Multivalent anti-CCR ribozymes for stem cell-based HIV type 1 gene therapy. AIDS Res. Hum. Retroviruses 2001, 17, 385-399. [CrossRef] [PubMed]

102. Bai, J.; Gorantla, S.; Banda, N.; Cagnon, L.; Rossi, J.; Akkina, R. Characterization of anti-CCR5 ribozyme-transduced CD34+ hematopoietic progenitor cells in vitro and in a SCID-hu mouse model in vivo. Mol. Ther. 2000, 1, 244-254. [CrossRef] [PubMed]

103. Jamieson, A.C.; Miller, J.C.; Pabo, C.O. Drug discovery with engineered zinc-finger proteins. Nat. Rev. Drug Discov. 2003, 2, 361-368. [CrossRef] [PubMed]

104. Tebas, P.; Stein, D.; Tang, W.W.; Frank, I.; Wang, S.Q.; Lee, G.; Spratt, S.K.; Surosky, R.T.; Giedlin, M.A.; Nichol, G.; et al. Gene editing of CCR5 in autologous CD4 T cells of persons infected with HIV. N. Engl. J. Med. 2014, 370, 901-910. [CrossRef] [PubMed]

105. Scarborough, R.J.; Gatignol, A. HIV and Ribozymes. Adv. Exp. Med. Biol. 2015, 848, 97-116. [CrossRef] [PubMed]

106. Cornu, T.I.; Mussolino, C.; Cathomen, T. Refining strategies to translate genome editing to the clinic. Nat. Med. 2017, 23, 415-423. [CrossRef] [PubMed]

107. Swamy, M.N.; Wu, H.; Shankar, P. Recent advances in RNAi-based strategies for therapy and prevention of HIV-1/AIDS. Adv. Drug Deliv. Rev. 2016, 103, 174-186. [CrossRef] [PubMed]

108. Symonds, G.P.; Johnstone, H.A.; Millington, M.L.; Boyd, M.P.; Burke, B.P.; Breton, L.R. The use of cell-delivered gene therapy for the treatment of HIV/AIDS. Immunol. Res. 2010, 48, 84-98. [CrossRef] [PubMed]

109. Ledger, S.; Howe, A.; Turville, S.; Aggarwal, A.; Savkovic, B.; Ong, A.; Wolstein, O.; Boyd, M.; Millington, M.; Gorry, P.R.; et al. Analysis and dissociation of anti-HIV effects of shRNA to CCR5 and the fusion inhibitor C46. J. Gene Med. 2018, 20, e3006. [CrossRef] [PubMed]

110. Vangelista, L.; Vento, S. The Expanding Therapeutic Perspective of CCR5 Blockade. Front. Immunol. 2017, 8, 1981. [CrossRef] [PubMed]

111. Lim, J.K.; Louie, C.Y.; Glaser, C.; Jean, C.; Johnson, B.; Johnson, H.; McDermott, D.H.; Murphy, P.M. Genetic deficiency of chemokine receptor CCR5 is a strong risk factor for symptomatic West Nile virus infection: A meta-analysis of 4 cohorts in the US epidemic. J. Infect. Dis. 2008, 197, 262-265. [CrossRef] [PubMed]

112. Glass, W.G.; McDermott, D.H.; Lim, J.K.; Lekhong, S.; Yu, S.F.; Frank, W.A.; Pape, J.; Cheshier, R.C.; Murphy, P.M. CCR5 deficiency increases risk of symptomatic West Nile virus infection. J. Exp. Med. 2006, 203, 35-40. [CrossRef] [PubMed]

113. Liu, Y.P.; Westerink, J.T.; ter Brake, O.; Berkhout, B. RNAi-inducing lentiviral vectors for anti-HIV-1 gene therapy. Methods Mol. Biol. 2011, 721, 293-311. [CrossRef] [PubMed]

114. Kumar, P.; Ban, H.S.; Kim, S.S.; Wu, H.; Pearson, T.; Greiner, D.L.; Laouar, A.; Yao, J.; Haridas, V.; Habiro, K.; et al. T cell-specific siRNA delivery suppresses HIV-1 infection in humanized mice. Cell 2008, 134, 577-586. [CrossRef] [PubMed]

115. ter Brake, O.; Legrand, N.; von Eije, K.J.; Centlivre, M.; Spits, H.; Weijer, K.; Blom, B.; Berkhout, B. Evaluation of safety and efficacy of RNAi against HIV-1 in the human immune system (Rag-2(-/-)gammac(-/-)) mouse model. Gene Ther. 2009, 16, 148-153. [CrossRef] [PubMed]

116. Suzuki, K.; Shijuuku, T.; Fukamachi, T.; Zaunders, J.; Guillemin, G.; Cooper, D.; Kelleher, A. Prolonged transcriptional silencing and $\mathrm{CPG}$ methylation induced by siRNAs targeted to the HIV-1 promoter region. J. RNAi Gene Silenc. 2005, 1, 66-78. [PubMed] 
117. Santat, L.; Paz, H.; Wong, C.; Li, L.; Macer, J.; Forman, S.; Wong, K.K.; Chatterjee, S. Recombinant AAV2 transduction of primitive human hematopoietic stem cells capable of serial engraftment in immune-deficient mice. Proc. Natl. Acad. Sci. USA 2005, 102, 11053-11058. [CrossRef] [PubMed]

118. Li, M.J.; Bauer, G.; Michienzi, A.; Yee, J.K.; Lee, N.S.; Kim, J.; Li, S.; Castanotto, D.; Zaia, J.; Rossi, J.J. Inhibition of HIV-1 infection by lentiviral vectors expressing Pol III-promoted anti-HIV RNAs. Mol. Ther. 2003, 8, 196-206. [CrossRef]

119. Akkina, R.; Banerjea, A.; Bai, J.; Anderson, J.; Li, M.J.; Rossi, J. siRNAs, ribozymes and RNA decoys in modeling stem cell-based gene therapy for HIV / AIDS. Anticancer Res. 2003, 23, 1997-2005. [PubMed]

120. Banerjea, A.; Li, M.J.; Bauer, G.; Remling, L.; Lee, N.S.; Rossi, J.; Akkina, R. Inhibition of HIV-1 by lentiviral vector-transduced siRNAs in T lymphocytes differentiated in SCID-hu mice and CD34+ progenitor cell-derived macrophages. Mol. Ther. 2003, 8, 62-71. [CrossRef]

121. Bauer, G.; Valdez, P.; Kearns, K.; Bahner, I.; Wen, S.F.; Zaia, J.A.; Kohn, D.B. Inhibition of human immunodeficiency virus-1 (HIV-1) replication after transduction of granulocyte colony-stimulating factor-mobilized CD34+ cells from HIV-1-infected donors using retroviral vectors containing anti-HIV-1 genes. Blood 1997, 89, 2259-2267. [PubMed]

122. Rosenzweig, M.; Marks, D.F.; Hempel, D.; Lisziewicz, J.; Johnson, R.P. Transduction of CD34+ hematopoietic progenitor cells with an antitat gene protects T-cell and macrophage progeny from AIDS virus infection. J. Virol. 1997, 71, 2740-2746. [PubMed]

123. Yu, M.; Leavitt, M.C.; Maruyama, M.; Yamada, O.; Young, D.; Ho, A.D.; Wong-Staal, F. Intracellular immunization of human fetal cord blood stem/progenitor cells with a ribozyme against human immunodeficiency virus type 1. Proc. Natl. Acad. Sci. USA 1995, 92, 699-703. [CrossRef] [PubMed]

124. Wang, G.; Zhao, N.; Berkhout, B.; Das, A.T. CRISPR-Cas based antiviral strategies against HIV-1. Virus Res. 2018, 244, 321-332. [CrossRef] [PubMed]

125. Herrera-Carrillo, E.; Berkhout, B. Attacking HIV-1 RNA versus DNA by sequence-specific approaches: RNAi versus CRISPR-Cas. Biochem. Soc. Trans. 2016, 44, 1355-1365. [CrossRef] [PubMed]

126. Hu, W.; Kaminski, R.; Yang, F.; Zhang, Y.; Cosentino, L.; Li, F.; Luo, B.; Alvarez-Carbonell, D.; Garcia-Mesa, Y.; Karn, J.; et al. RNA-directed gene editing specifically eradicates latent and prevents new HIV-1 infection. Proc. Natl. Acad. Sci. USA 2014, 111, 11461-11466. [CrossRef] [PubMed]

127. Wang, Z.; Pan, Q.; Gendron, P.; Zhu, W.; Guo, F.; Cen, S.; Wainberg, M.A.; Liang, C. CRISPR/Cas9-Derived Mutations Both Inhibit HIV-1 Replication and Accelerate Viral Escape. Cell Rep. 2016, 15, 481-489. [CrossRef] [PubMed]

128. Man, D.; Sansbury, B.; Bialk, P.; Bloh, K.; Kolb, E.A.; Kmiec, E.B. Target Site Mutagenesis during Crispr/ Cas 9/Single-Stranded- Oligonucleotide Directed Gene Editing for Sickle Cell Anemia. Blood 2016, 128, 4706.

129. White, M.K.; Kaminski, R.; Young, W.B.; Roehm, P.C.; Khalili, K. CRISPR Editing Technology in Biological and Biomedical Investigation. J. Cell. Biochem. 2017, 118, 3586-3594. [CrossRef] [PubMed]

130. Yin, C.; Zhang, T.; Qu, X.; Zhang, Y.; Putatunda, R.; Xiao, X.; Li, F.; Xiao, W.; Zhao, H.; Dai, S.; et al. In Vivo Excision of HIV-1 Provirus by saCas9 and Multiplex Single-Guide RNAs in Animal Models. Mol. Ther. 2017, 25, 1168-1186. [CrossRef] [PubMed]

131. Kunze, C.; Borner, K.; Kienle, E.; Orschmann, T.; Rusha, E.; Schneider, M.; Radivojkov-Blagojevic, M.; Drukker, M.; Desbordes, S.; Grimm, D.; et al. Synthetic AAV/CRISPR vectors for blocking HIV-1 expression in persistently infected astrocytes. Glia 2018, 66, 413-427. [CrossRef] [PubMed]

132. Ahlenstiel, C.L.; Suzuki, K.; Marks, K.; Symonds, G.P.; Kelleher, A.D. Controlling HIV-1: Non-Coding RNA Gene Therapy Approaches to a Functional Cure. Front. Immunol. 2015, 6, 474. [CrossRef] [PubMed]

133. Suzuki, K.; Juelich, T.; Lim, H.; Ishida, T.; Watanebe, T.; Cooper, D.A.; Rao, S.; Kelleher, A.D. Closed chromatin architecture is induced by an RNA duplex targeting the HIV-1 promoter region. J. Biol. Chem. 2008, 283, 23353-23363. [CrossRef] [PubMed]

134. Ahlenstiel, C.; Mendez, C.; Lim, S.T.; Marks, K.; Turville, S.; Cooper, D.A.; Kelleher, A.D.; Suzuki, K. Novel RNA Duplex Locks HIV-1 in a Latent State via Chromatin-mediated Transcriptional Silencing. Mol. Ther. Nucleic Acids 2015, 4, e261. [CrossRef] [PubMed]

135. Suzuki, K.; Hattori, S.; Marks, K.; Ahlenstiel, C.; Maeda, Y.; Ishida, T.; Millington, M.; Boyd, M.; Symonds, G.; Cooper, D.A.; et al. Promoter Targeting shRNA Suppresses HIV-1 Infection In vivo Through Transcriptional Gene Silencing. Mol. Ther. Nucleic Acids 2013, 2, e137. [CrossRef] [PubMed] 
136. Zhang, M.; Poh, T.Y.; Louache, F.; Sundell, I.B.; Yuan, J.; Evans, S.; Koka, P.S. Rescue of multi-lineage hematopoiesis during HIV-1 infection by human c-mpl gene transfer and reconstitution of CD34+ progenitor cells in vivo. J. Stem Cells 2009, 4, 161-177. [PubMed]

137. Anderson, J.; Akkina, R. Human immunodeficiency virus type 1 restriction by human-rhesus chimeric tripartite motif 5alpha (TRIM 5alpha) in CD34(+) cell-derived macrophages in vitro and in T cells in vivo in severe combined immunodeficient (SCID-hu) mice transplanted with human fetal tissue. Hum. Gene Ther. 2008, 19, 217-228. [CrossRef] [PubMed]

138. Dimitrova, D.I.; Yang, X.; Reichenbach, N.L.; Karakasidis, S.; Sutton, R.E.; Henderson, E.E.; Rogers, T.J.; Suhadolnik, R.J. Lentivirus-mediated transduction of PKR into CD34(+) hematopoietic stem cells inhibits HIV-1 replication in differentiated T cell progeny. J. Interferon Cytokine Res. 2005, 25, 345-360. [CrossRef] [PubMed]

139. Leibman, R.S.; Richardson, M.W.; Ellebrecht, C.T.; Maldini, C.R.; Glover, J.A.; Secreto, A.J.; Kulikovskaya, I.; Lacey, S.F.; Akkina, S.R.; Yi, Y.; et al. Supraphysiologic control over HIV-1 replication mediated by CD8 T cells expressing a re-engineered CD4-based chimeric antigen receptor. PLoS Pathog. 2017, 13, e1006613. [CrossRef] [PubMed]

140. Liu, L.; Patel, B.; Ghanem, M.H.; Bundoc, V.; Zheng, Z.; Morgan, R.A.; Rosenberg, S.A.; Dey, B.; Berger, E.A. Novel CD4-Based Bispecific Chimeric Antigen Receptor Designed for Enhanced Anti-HIV Potency and Absence of HIV Entry Receptor Activity. J. Virol. 2015, 89, 6685-6694. [CrossRef] [PubMed]

141. Hammer, O. CD19 as an attractive target for antibody-based therapy. MAbs 2012, 4, 571-577. [CrossRef] [PubMed]

142. Pulsipher, M.A. Are CAR T cells better than antibody or HCT therapy in B-ALL? Hematol. Am. Soc. Hematol. Educ. Program 2018, 2018, 16-24. [CrossRef] [PubMed]

143. Miliotou, A.N.; Papadopoulou, L.C. CAR T-cell Therapy: A New Era in Cancer Immunotherapy. Curr. Pharm. Biotechnol. 2018, 19, 5-18. [CrossRef] [PubMed]

144. Davila, M.L.; Brentjens, R.J. CD19-Targeted CAR T cells as novel cancer immunotherapy for relapsed or refractory B-cell acute lymphoblastic leukemia. Clin. Adv. Hematol. Oncol. 2016, 14, 802-808. [PubMed]

145. Quintas-Cardama, A. CD19 directed CAR T cell therapy in diffuse large B-cell lymphoma. Oncotarget 2018, 9, 29843-29844. [CrossRef] [PubMed]

146. Ali, A.; Kitchen, S.G.; Chen, I.S.Y.; Ng, H.L.; Zack, J.A.; Yang, O.O. HIV-1-Specific Chimeric Antigen Receptors Based on Broadly Neutralizing Antibodies. J. Virol. 2016, 90, 6999-7006. [CrossRef] [PubMed]

147. Liu, B.; Zou, F.; Lu, L.; Chen, C.; He, D.; Zhang, X.; Tang, X.; Liu, C.; Li, L.; Zhang, H. Chimeric Antigen Receptor T Cells Guided by the Single-Chain Fv of a Broadly Neutralizing Antibody Specifically and Effectively Eradicate Virus Reactivated from Latency in CD4+ T Lymphocytes Isolated from HIV-1-Infected Individuals Receiving Suppressive Combined Antiretroviral Therapy. J. Virol. 2016, 90, 9712-9724. [CrossRef] [PubMed]

148. Hale, M.; Mesojednik, T.; Romano Ibarra, G.S.; Sahni, J.; Bernard, A.; Sommer, K.; Scharenberg, A.M.; Rawlings, D.J.; Wagner, T.A. Engineering HIV-Resistant, Anti-HIV Chimeric Antigen Receptor T Cells. Mol. Ther. 2017, 25, 570-579. [CrossRef] [PubMed]

149. Zhen, A.; Kamata, M.; Rezek, V.; Rick, J.; Levin, B.; Kasparian, S.; Chen, I.S.; Yang, O.O.; Zack, J.A.; Kitchen, S.G. HIV-specific Immunity Derived From Chimeric Antigen Receptor-engineered Stem Cells. Mol. Ther. 2015, 23, 1358-1367. [CrossRef] [PubMed]

150. Zhen, A.; Peterson, C.W.; Carrillo, M.A.; Reddy, S.S.; Youn, C.S.; Lam, B.B.; Chang, N.Y.; Martin, H.A.; Rick, J.W.; Kim, J.; et al. Long-term persistence and function of hematopoietic stem cell-derived chimeric antigen receptor T cells in a nonhuman primate model of HIV/AIDS. PLoS Pathog. 2017, 13, e1006753. [CrossRef] [PubMed]

151. Luo, X.M.; Maarschalk, E.; O'Connell, R.M.; Wang, P.; Yang, L.; Baltimore, D. Engineering human hematopoietic stem/progenitor cells to produce a broadly neutralizing anti-HIV antibody after in vitro maturation to human B lymphocytes. Blood 2009, 113, 1422-1431. [CrossRef] [PubMed]

152. Poznansky, M.C.; La Vecchio, J.; Silva-Arietta, S.; Porter-Brooks, J.; Brody, K.; Olszak, I.T.; Adams, G.B.; Ramstedt, U.; Marasco, W.A.; Scadden, D.T. Inhibition of human immunodeficiency virus replication and growth advantage of CD4+ T cells and monocytes derived from CD34+ cells transduced with an intracellular antibody directed against human immunodeficiency virus type 1 Tat. Hum. Gene Ther. 1999, 10, 2505-2514. [CrossRef] [PubMed] 
153. Prince, A.M.; Reesink, H.; Pascual, D.; Horowitz, B.; Hewlett, I.; Murthy, K.K.; Cobb, K.E.; Eichberg, J.W. Prevention of HIV infection by passive immunization with HIV immunoglobulin. AIDS Res. Hum. Retroviruses 1991, 7, 971-973. [CrossRef] [PubMed]

154. Morris, L.; Mkhize, N.N. Prospects for passive immunity to prevent HIV infection. PLoS Med. 2017, 14, e1002436. [CrossRef] [PubMed]

155. Balazs, A.B.; West, A.P., Jr. Antibody gene transfer for HIV immunoprophylaxis. Nat. Immunol. 2013, 14, 1-5. [CrossRef] [PubMed]

156. Balazs, A.B.; Chen, J.; Hong, C.M.; Rao, D.S.; Yang, L.; Baltimore, D. Antibody-based protection against HIV infection by vectored immunoprophylaxis. Nature 2011, 481, 81-84. [CrossRef] [PubMed]

157. Badamchi-Zadeh, A.; Tartaglia, L.J.; Abbink, P.; Bricault, C.A.; Liu, P.T.; Boyd, M.; Kirilova, M.; Mercado, N.B.; Nanayakkara, O.S.; Vrbanac, V.D.; et al. Therapeutic Efficacy of Vectored PGT121 Gene Delivery in HIV-1-Infected Humanized Mice. J. Virol. 2018, 92. [CrossRef] [PubMed]

158. Cyranoski, D.; Ledford, H. Genome-edited baby claim provokes international outcry. Nature 2018, 563, 607-608. [CrossRef] [PubMed]

159. Frankel, M.S.; Chapman, A.R. Genetic technologies. Facing inheritable genetic modifications. Science 2001, 292, 1303. [CrossRef] [PubMed]

160. Zhang, X.H.; Tee, L.Y.; Wang, X.G.; Huang, Q.S.; Yang, S.H. Off-target Effects in CRISPR/Cas9-mediated Genome Engineering. Mol. Ther. Nucleic Acids 2015, 4, e264. [CrossRef] [PubMed]

161. Keep off-target effects in focus. Nat. Med. 2018, 24, 1081. [CrossRef] [PubMed]

162. Aryal, N.K.; Wasylishen, A.R.; Lozano, G. CRISPR/Cas9 can mediate high-efficiency off-target mutations in mice in vivo. Cell Death Dis. 2018, 9, 1099. [CrossRef] [PubMed]

163. Ormond, K.E.; Mortlock, D.P.; Scholes, D.T.; Bombard, Y.; Brody, L.C.; Faucett, W.A.; Garrison, N.A.; Hercher, L.; Isasi, R.; Middleton, A.; et al. Human Germline Genome Editing. Am. J. Hum. Genet. 2017, 101, 167-176. [CrossRef] [PubMed]

(C) 2019 by the author. Licensee MDPI, Basel, Switzerland. This article is an open access article distributed under the terms and conditions of the Creative Commons Attribution (CC BY) license (http:/ / creativecommons.org/licenses/by/4.0/). 